\title{
IRF2BP2 wt Allele
}

National Cancer Institute

\section{Source}

National Cancer Institute. IRF2BP2 wt Allele. NCI Thesaurus. Code C107665.

Human IRF2BP2 wild-type allele is located in the vicinity of $1 \mathrm{q} 42.3$ and is approximately 5 $\mathrm{kb}$ in length. This allele, which encodes interferon regulatory factor 2-binding protein 2 , is involved in the repression of interferon gene expression. 